\title{
Massive splenomegaly
}

\author{
Hugo L Paz-Y-Mar, ${ }^{1}$ Alexei Gonzalez-Estrada, ${ }^{2}$ M Chadi Alraies ${ }^{1}$
}

1 Department of Hospital Medicine, Cleveland Clinic, Cleveland, Ohio, USA

${ }^{2}$ Department of Internal Medicine, Cleveland Clinic Cleveland, Ohio, USA

\section{Correspondence to} Dr M Chadi Alraies, alraies@hotmail.com

\section{DESCRIPTION}

A 35 -year-old healthy man presented with a 1-year history of weight loss, easy bruising, night sweats, epistaxis and abdominal pain. $\mathrm{He}$ denied any medical comorbidities or any history of recent travelling. On physical examination, he had mild left upper quadrant abdominal pain with massively enlarged spleen crossing the midline. A complete blood count revealed pancytopenia: haemoglobin $5.3 \mathrm{~g} / \mathrm{dL}$, white cell count $1.97000 / \mu \mathrm{L} \quad(80 \%$ lymphocytes) and platelet count $26000 / \mu \mathrm{L}$. Splenomegaly was confirmed on a coronal CT image of the abdomen and pelvis (figure 1) without any evidence of rupture or bleed. The patient was admitted to the hospital for a thorough evaluation. Peripheral blood flow cytometry revealed atypical cells positive for hairy cell leukaemia markers, as

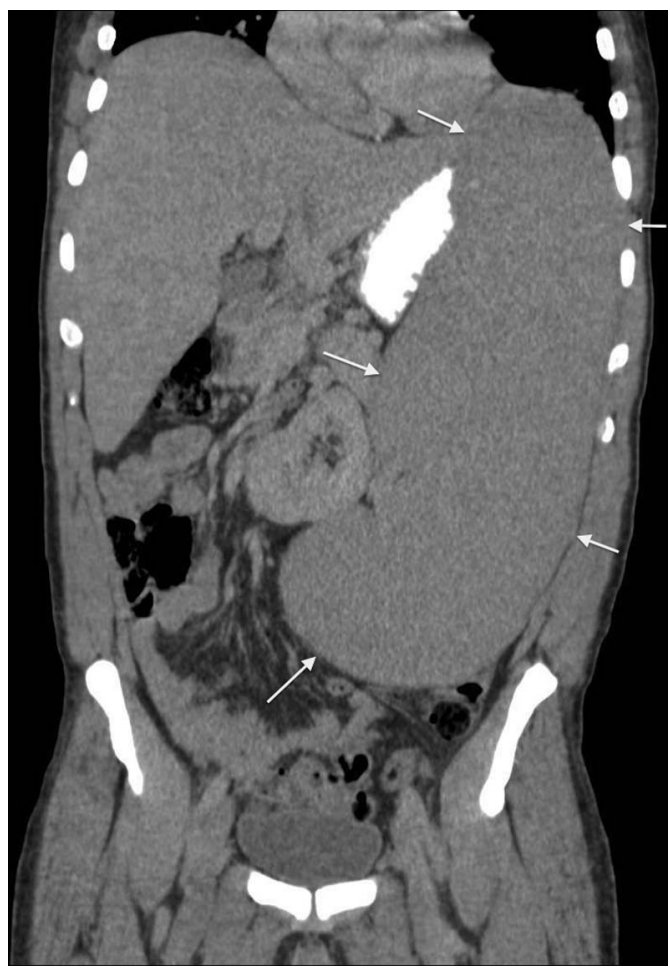

Figure 1 CT scan of the abdomen and pelvis showing splenomegaly without any evidence of rupture or bleed. well as B-cell markers. A bone marrow biopsy confirmed the diagnosis of hairy cell leukaemia.

Splenomegaly is a common finding in multiple diseases; however, massive enlargement of the spleen is seen in few conditions. Most authors define massive splenomegaly when the spleen reaches the iliac crest, crosses the midline or weights more than $1500 \mathrm{~g}$. The most common aetiologies of massive splenomegaly include haematological disorders (chronic myeloid leukamia, agnogenic myeloid metaplasia, polycythaemia vera, essential thrombocythaemia, indolent lymphomas, hairy cell leukaemia, $\beta$-thalassaemia major), infectious diseases (visceral leishmaniasis, malaria) and infiltrative conditions (Gaucher disease). ${ }^{12}$

The patient had a complete remission after treatment with intermittent cladribine therapy followed by rituximab.

\section{Learning points}

- The clinical manifestations of hairy cell leukaemia are the result of bone marrow, liver and spleen infiltration by malignant cells.

- Splenomegaly is a common finding in multiple diseases; however, massive enlargement of the spleen is seen in few conditions.

- Flow cytometry and bone marrow biopsy are the recommended work-up for massive splenomegaly.

Competing interests None.

Patient consent Obtained.

Provenance and peer review Not commissioned; externally peer reviewed.

\section{REFERENCES}

1 O'Reilly RA. Splenomegaly in 2,505 patients in a large university medical center from 1913 to 1995.1913 to 1962: 2,056 patients. West J Med 1998:169:78-87.

2 Forconi F. Hairy cell leukaemia: biological and clinical overview from immunogenetic insights. Hematol Oncol 2011;29:55-66.
To cite: Paz-Y-Mar HL, Gonzalez-Estrada A, Alraies MC. BMJ Case Rep Published online: [please include Day Month Year] doi:10.1136/bcr-2013200515 


\section{Images in...}

Copyright 2013 BMJ Publishing Group. All rights reserved. For permission to reuse any of this content visit http://group.bmj.com/group/rights-licensing/permissions.

BMJ Case Report Fellows may re-use this article for personal use and teaching without any further permission.

Become a Fellow of BMJ Case Reports today and you can:

- Submit as many cases as you like

- Enjoy fast sympathetic peer review and rapid publication of accepted articles

- Access all the published articles

- Re-use any of the published material for personal use and teaching without further permission

For information on Institutional Fellowships contact consortiasales@bmjgroup.com

Visit casereports.bmj.com for more articles like this and to become a Fellow 